\section{FeTiMM - A new oxybarometer for mafic to felsic magmas}

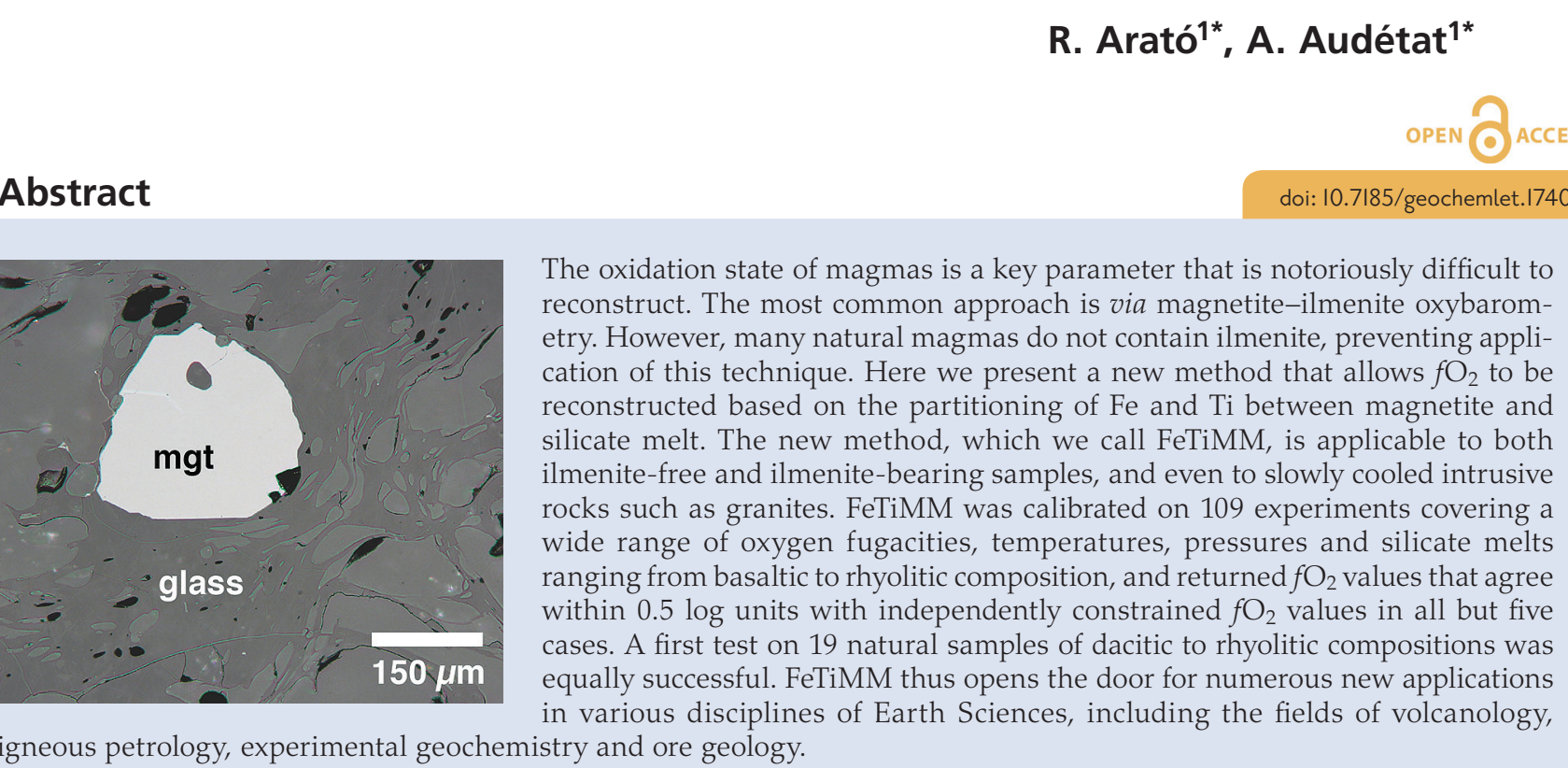

Received 26 July 2017 | Accepted 18 September 2017 | Published 25 October 2017

\section{Introduction}

Oxygen fugacity is an important thermodynamic parameter in magmatic systems because it exerts a first order control on phase equilibria as well as on mineral-melt and fluid-melt partition coefficients. The most commonly used and most reliable way to reconstruct magmatic $f_{2}$ is via magnetite-ilmenite oxybarometry (e.g., Buddington and Lindsley, 1964; Carmichael, 1967; Stormer, 1983; Andersen and Lindsley, 1988; Ghiorso and Sack, 1991; Lattard et al., 2005; Ghiorso and Evans, 2008). Alternative approaches are based on (i) the $\mathrm{Fe}^{2+} / \mathrm{Fe}^{3+}$ ratio of whole rocks (Kress and Carmichael, 1989; Putirka, 2016), (ii) mineral reactions involving olivine, pyroxene, and/or sphene (Frost and Lindsley, 1992; Lindsley and Frost, 1992; Andersen et al., 1993; Xirouchakis et al., 2001), (iii) biotite, K-feldspar and magnetite (Wones and Eugster, 1965; Wones, 1981), (iv) zircon Ce (and Eu) anomalies (Ballard et al., 2002; Trail et al., 2012; Smythe and Brenan, 2016), and (v) single amphibole oxybarometry (Ridolfi et al., 2010). However, despite these various approaches, reconstruction of magmatic $f_{2}$ in igneous rocks remains difficult, particularly in the case of intrusives, because during slow cooling Fe-Ti-oxide minerals usually get either reset or altered. Furthermore, many magmas do not contain ilmenite but only magnetite (Frost and Lindsley, 1991), precluding the application of magnetite-ilmenite oxybarometry.

\section{Calibration of the FeTiMM Oxybarometer}

The aim of this study was to develop an oxybarometer that is based on element partitioning between a mineral and silicate melt, such that it can be applied to samples in which these phases occur as inclusions within phenocrysts and thus were protected from re-equilibration and alteration during slow cooling. Iron partitioning between magnetite and melt is a promising candidate because magnetite is a common mineral and because magnetite solubility in silicic melts has been shown to depend on $\mathrm{fO}_{2}$ (Gaillard et al., 2001). However, magnetite solubility (and thus Fe partitioning between magnetite and silicate melt) also depends strongly on temperature (T) and melt composition. At constant $\mathrm{fO}_{2}$ and $\mathrm{T}$, magnetite solubility increases by a factor of up to 6 as the alumina saturation index (ASI; defined as the molar $\mathrm{Al}_{2} \mathrm{O}_{3} /\left(\mathrm{Na}_{2} \mathrm{O}+\mathrm{K}_{2} \mathrm{O}\right.$ $+\mathrm{CaO}$ ) ratio) decreases from 1.0 to 0.6. Magnetite solubility is thus not suitable as an oxybarometer unless T and ASI can be extremely well constrained, which is commonly difficult in natural samples (Arató and Audétat, 2017a). However, we noticed that the effect of ASI on magnetite solubility is similar to that on $\mathrm{TiO}_{2}$ solubility (Kularatne and Audétat, 2014), with the latter being independent on $\mathrm{fO}_{2}$. Hence, the effect of melt composition may be diminished by dividing the mgt-melt partition coefficient of $\mathrm{Fe}\left(\mathrm{D}_{\mathrm{Fe}}{ }^{\mathrm{mgt} / \mathrm{melt}}\right)$ by that of $\mathrm{Ti}\left(\mathrm{D}_{\mathrm{Ti}}{ }^{\mathrm{mgt} / \mathrm{melt}}\right)$.

We tested this idea first on a set of 50 of our own experiments conducted in the system magnetite- $\mathrm{H}_{2} \mathrm{O}$-rhyolite melt at various oxygen fugacities, temperatures, pressures, melt ASIs, and magnetite compositions (Arató and Audétat,

1. Bayerisches Geoinstitut, Universität Bayreuth, 95440 Bayreuth, Germany

Corresponding authors (email: robert.arato@uni-bayreuth.de; andreas.audetat@uni-bayreuth.de) 
2017b; Table S-1). The results (Fig. S-1) revealed that the melt composition effect indeed gets greatly reduced in this way, and that the $\mathrm{Fe}-\mathrm{Ti}$ exchange coefficient between magnetite and silicate melt, $\mathrm{D}_{\mathrm{Fe}-\mathrm{Ti}}{ }^{\mathrm{mgt} / \mathrm{melt}}=\left(\mathrm{D}_{\mathrm{FeOtot}}{ }^{\mathrm{mgt} / \mathrm{melt}}\right) /\left(\mathrm{D}_{\mathrm{TiO} 2}{ }^{\mathrm{mgt} / \mathrm{melt}}\right)$, depends most strongly on $\mathrm{fO}_{2}$, with the effect of temperature becoming negligible. In a second step we extended the dataset by 59 experiments from 14 different studies performed at $750-1100{ }^{\circ} \mathrm{C}, 0.1-700 \mathrm{MPa}$, oxygen fugacities of -1.3 to $+5.5 \log$ units relative to the fayalite-magnetite-quartz buffer $(\triangle \mathrm{FMQ}-1.3$ to $\triangle \mathrm{FMQ}+5.5)$, with melt compositions of 48-79 wt. $\% \mathrm{SiO}_{2}$ and $\mathrm{ASI}=0.3-1.3$, and magnetite compositions of $0.01-28$ wt. $\% \mathrm{TiO}_{2}$. These 59 experiments were left after screening 33 experimental studies with a total of $>1600$ experiments (Table S-2) for the following criteria: (i) $\mathrm{fO}_{2}$ was controlled experimentally, (ii) magnetite coexists with ilmenite in at least some of the experiments, (iii) compositional data for magnetite, silicate melt, \pm ilmenite are available, (iv) the reported average compositions of magnetite and ilmenite represent equilibrium pairs (Bacon and Hirschmann, 1988), and (v) the average compositions of magnetite and silicate melt pass a similar test that we developed to check for magnetitemelt equilibrium (Fig. S-2). In this second step, we focused on ilmenite-saturated experiments to be able to constrain $\mathrm{fO}_{2}$ values independently via magnetite-ilmenite oxybarometry. In nine cases, the reported experimental $\mathrm{fO}_{2}$ values deviated by more than $1.0 \log$ unit $f \mathrm{O}_{2}$ from the values obtained via magnetite-ilmenite oxybarometry (Ghiorso and Evans, 2008; Fig. S-3), suggesting problems with the control of experimental $\mathrm{fO}_{2}$ (Matjuschkin et al., 2015). We thus relied on the $\mathrm{fO}_{2}$ values calculated via magnetite-ilmenite oxybarometry for all 59 ilmenite-saturated experiments. To account for the large range of melt compositions, it was necessary to include $\mathrm{MgO}$ in the melt compositional parameter. Based on the extended dataset of 109 experiments we developed a model (which we hereinafter call FeTiMM) that allows $\mathrm{fO}_{2}$ to be calculated as a function of $\mathrm{D}_{\mathrm{Fe}-\mathrm{Ti}}{ }^{\mathrm{mgt}}$ /melt (with $\mathrm{FeO}_{\text {tot }}$ and $\mathrm{TiO}_{2}$ measured in weight percent, and the melt composition reported dry) and the melt compositional parameter $\mathrm{AMCNK}=$ molar $\mathrm{Al}_{2} \mathrm{O}_{3} /$ $\left(\mathrm{CaO}+\mathrm{Na}_{2} \mathrm{O}+\mathrm{K}_{2} \mathrm{O}+\mathrm{MgO}\right)$ :

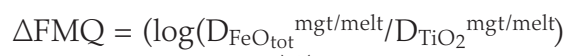

$\left.+0.137^{*} \mathrm{AMCNK}+0.102\right) /\left(0.288^{*} \mathrm{AMCNK}+0.054\right)$ Eq.

The rationale behind this equation is depicted in Figure 1. The overall uncertainty of the FeTiMM model, calculated from the errors of the fits in Figure 1b,c propagated into Equation 1 (see Supplementary Information) increases from $\pm 0.2-0.3 \log$ units $f \mathrm{O}_{2}$ at $\leq \Delta \mathrm{FMQ}+1.5$, to $\pm 0.3-0.5 \log$ units $f_{2}$ at $\triangle \mathrm{FMQ}+4.5$ (Supplementary Table S-1). The performance of FeTiMM on the 59 ilmenite-saturated experiments is shown in Figure 2. As explained above, we relied on $\mathrm{fO}_{2}$ values calculated via magnetite-ilmenite oxybarometry (Ghiorso and Evans, 2008) for this test. The uncertainty of the latter model was not explicitly stated (Ghiorso and Evans, 2008), but based on their Figure 27 it can be estimated at $c a . \pm 0.3 \log$ units at reducing conditions $(\triangle \mathrm{FMQ}-1$ to $\triangle \mathrm{FMQ}+1)$ to $c a . \pm 0.5 \log$ units at strongly oxidising conditions $(\triangle \mathrm{FMQ}+4.5$; not considering a group of outliers), i.e. similar to the uncertainty associated with our model. Within these errors, 63 out of the 109 experiments show perfect agreement between the two methods and all but five experiments return $f \mathrm{O}_{2}$ values that agree within $\leq 0.5$ $\log$ units. No correlations are evident between the degree of correspondence and $\mathrm{fO}_{2}$, temperature, melt $\mathrm{SiO}_{2}$ content, ASI, or magnetite composition (Fig. S-4), suggesting that FeTiMM works equally well over the entire range of the investigated P-T-X conditions. It should be mentioned that any misfit can result from various sources including (i) analytical errors, (ii) experimental problems, as well as (iii) weaknesses in either model.
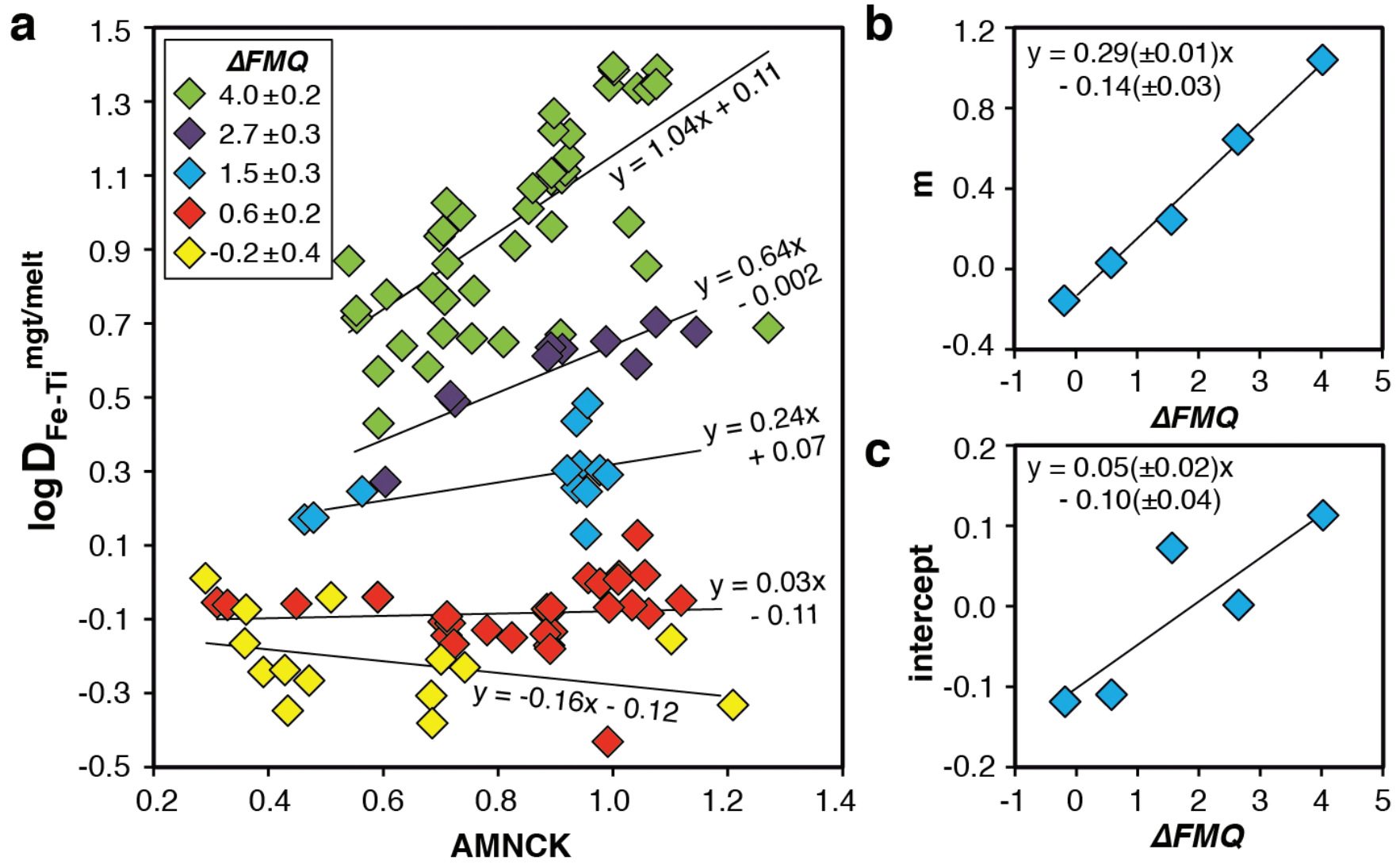

Figure 1 Development of the FeTiMM model. (a) 109 experimental data points (59 ilmenite-saturated; 50 ilmenite-undersaturated) were split into five groups of similar oxygen fugacity, through which linear regressions were fit. $D_{\mathrm{Fe}-\mathrm{Ti}_{\mathrm{mgt}} / \mathrm{melt}}=\left(\mathrm{D}_{\mathrm{FeOtot}} \mathrm{mgt} / \mathrm{melt}\right) /$ $\left(\mathrm{D}_{\mathrm{TiO} 2}{ }^{\mathrm{mgt} / \mathrm{melt}}\right) ; \mathrm{AMCNK}=$ molar $\mathrm{Al}_{2} \mathrm{O}_{3} /\left(\mathrm{MgO}+\mathrm{CaO}+\mathrm{Na}_{2} \mathrm{O}+\mathrm{K}_{2} \mathrm{O}\right)$. (b,c) Variation of the slopes and intercepts of the linear fits in $(\mathrm{a})$ as a function of oxygen fugacity expressed in log unit deviations from the fayalite-magnetite-quartz (FMQ) buffer. 


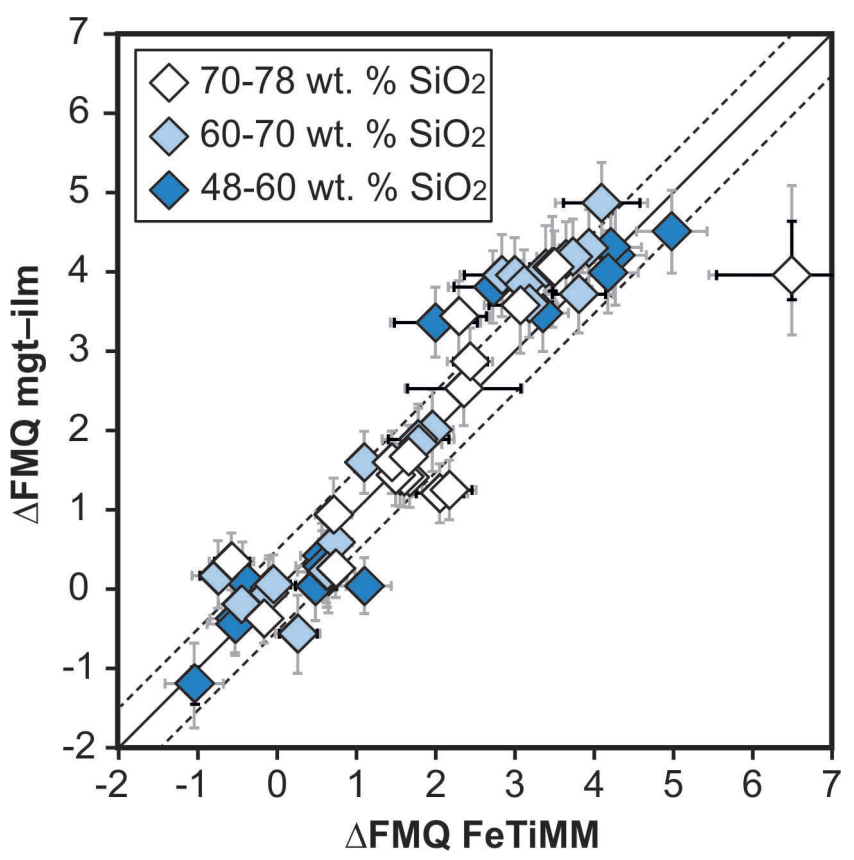

Figure 2 Performance of FeTIMM in ilmenite-saturated magmas. Oxygen fugacities (expressed in log units relative to the FMQ buffer) obtained via FeTiMM are compared with ones obtained via magnetite-ilmenite oxybarometry using the model of Ghiorso and Evans (2008). The data are divided into three groups of contrasting melt $\mathrm{SiO}_{2}$. Black error bars (in most cases smaller than symbol size) denote the analytical error, whereas the grey error bars denote the overall error that includes both the analytical scatter and the error inherent to the model. Details about the calculation of errors are provided in the Supplementary Information.

\section{Tests on Additional Ilmenite- Undersaturated Experiments}

As discussed above, Equation 1 was derived from a database that comprises 50 ilmenite-undersaturated, rhyolitic experiments, plus 59 ilmenite-saturated, basaltic to rhyolitic experiments. It remains to be tested whether FeTiMM works also for ilmenite-undersaturated intermediate to mafic magmas. However, in ilmenite-undersaturated experiments $\mathrm{fO}_{2}$ cannot be independently constrained via magnetite-ilmenite thermobarometry, which forces us to rely on reported experimental $\mathrm{fO}_{2}$ values even if the test with the ilmenite-saturated experiments (Fig. S-3) revealed that these values are not always reliable. To reduce the chance of including erroneous $f \mathrm{O}_{2}$ reference values, we restricted our choice of ilmenite-undersaturated experiments to studies which comprised both ilmenite-undersaturated and ilmenite-saturated experiments, and which in the latter case showed good agreement between the reported experimental and magnetite-ilmenite-based $\mathrm{fO}_{2}$ values. This approach returned 27 data points from 5 different studies (Table S-1), excluding 22 data points that did not pass the $\mathrm{Mn} / \mathrm{Mg}$ magnetite-melt equilibrium test mentioned above. The performance of FeTiMM on these 27 literature-based experiments plus 50 of our own ilmenite-undersaturated experiments is shown in Figure 3. The data in Figure 3 show a larger scatter than those in Figure 2, which is likely due to errors in the reported experimental $f_{2}$ values (cf. Fig. S-3). Nevertheless, within the error quoted for FeTiMM, 7 of the 27 experiments return $f_{2}$ values that agree between the two methods and all but 5 experiments show a correspondence within $0.5 \mathrm{log}$ units. Again, no correlations are evident between the degree of $\mathrm{fO}_{2}$ correspondence and other key variables (Fig. S-5), suggesting that FeTiMM works equally well for mafic as for silicic rocks.

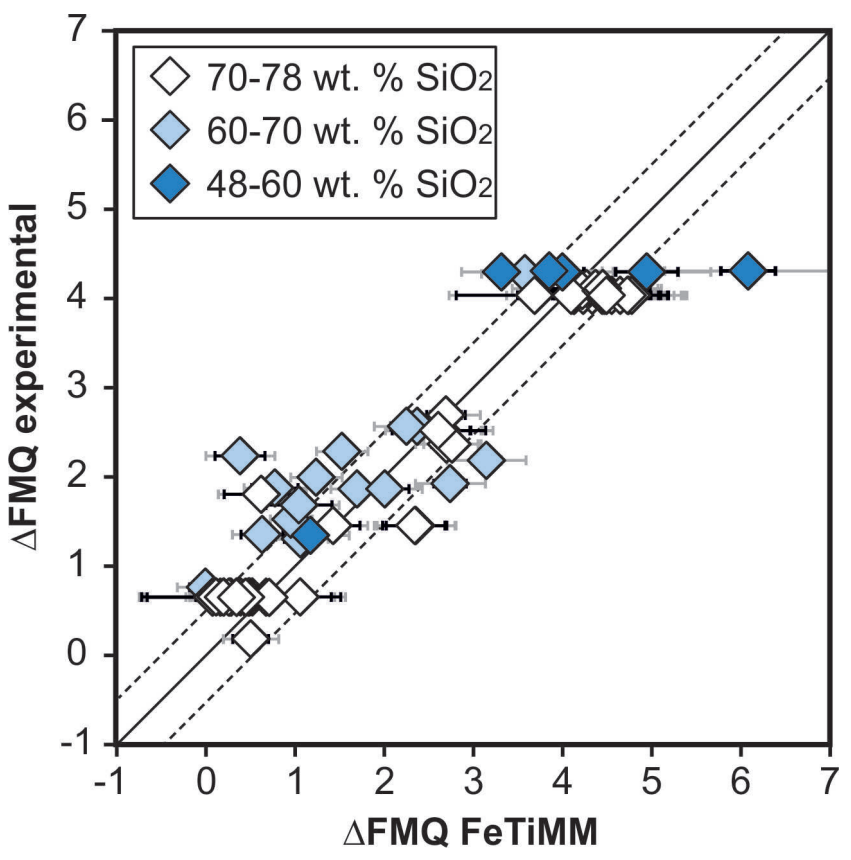

Figure 3 Performance of FeTiMM in ilmenite-undersaturated magmas. Due to the lack of ilmenite, one has to rely on the reported experimentally imposed $\mathrm{fO}_{2}$ values, which are associated with considerable (but unknown) uncertainty. Correspondingly, error bars in y-axis direction cannot be displayed. See Figure 2 for abbreviations and the meaning of the black and grey error bars in $\mathrm{x}$-axis direction.

In summary, the results in Figures 2 and 3 suggest that FeTiMM provides reliable $\mathrm{fO}_{2}$ estimates for both ilmenite-saturated and ilmenite-undersaturated magmas over the entire range of basaltic to rhyolitic compositions. It should be mentioned that none of the investigated melt compositions plot in the alkaline field (Macdonald and Katsura, 1964) in the total alkali vs. $\mathrm{SiO}_{2}$ (TAS) diagram (Le Maitre et al., 1989), so the performance of FeTiMM in highly alkaline magmas is not known yet. However, 102 out of the 136 data points plotted in Figures 2 and 3 are peralkaline according to molar $\mathrm{Al}_{2} \mathrm{O}_{3} /$ $\left(\mathrm{Na}_{2} \mathrm{O}+\mathrm{K}_{2} \mathrm{O}+\mathrm{CaO}\right)(=\mathrm{ACNK})$, with 17 melts having ACNK values $<0.7$.

\section{Application to Natural Samples}

The results of a first application of FeTiMM to 19 natural samples of rhyolitic to dacitic composition are shown in Figure 4. Details on the samples and analytical methods can be found in Arató and Audétat (2017a). All samples were ilmenite-saturated, such that $\mathrm{fO}_{2}$ could be independently constrained via magnetite-ilmenite oxybarometry. Coexistence of analysed magnetite, ilmenite and silicate melt was verified by means of the $\mathrm{Mg} / \mathrm{Mn}$ magnetite-ilmenite partitioning test (Bacon and Hirschmann, 1988) plus our own $\mathrm{Mn} / \mathrm{Mg}$ magnetite-melt partitioning test described in the Supplementary Information. In all but one sample, FeTiMM returned $f_{2}$ values that agree within $0.5 \log$ units with those obtained via magnetiteilmenite oxybarometry (Fig. 4).

One of the main advantages of FeTiMM is that it can be applied to magmas that do not contain ilmenite, which is true for many igneous rocks of mafic to felsic composition, particularly for those that are alkali-rich (Lindsley and Frost, 1992). Another major advantage of the method is that it can be applied to slowly cooled and/or altered rocks if magnetite and silicate melt are present as inclusions within phenocrysts (preferably quartz) and are analysed as entities by LA-ICP-MS, thereby effectively reversing compositional heterogeneities 
that developed within the inclusions during slow cooling. The sole disadvantage of FeTiMM is that it requires knowledge of the silicate melt composition. This can be readily accomplished in rapidly quenched, volcanic samples with glassy matrix, but is a bit more difficult in holocrystalline, porphyritic samples (for fresh samples selective analysis of the matrix suffices), and can be challenging in holocrystalline, coarse grained samples. In the latter samples, both magnetite and silicate melt need to be analysed as inclusions within phenocrysts, with the quantification of melt compositions requiring re-homogenisation experiments and/or constraints from whole rock data (Audétat and Lowenstern, 2014; Arató and Audétat, 2017a).

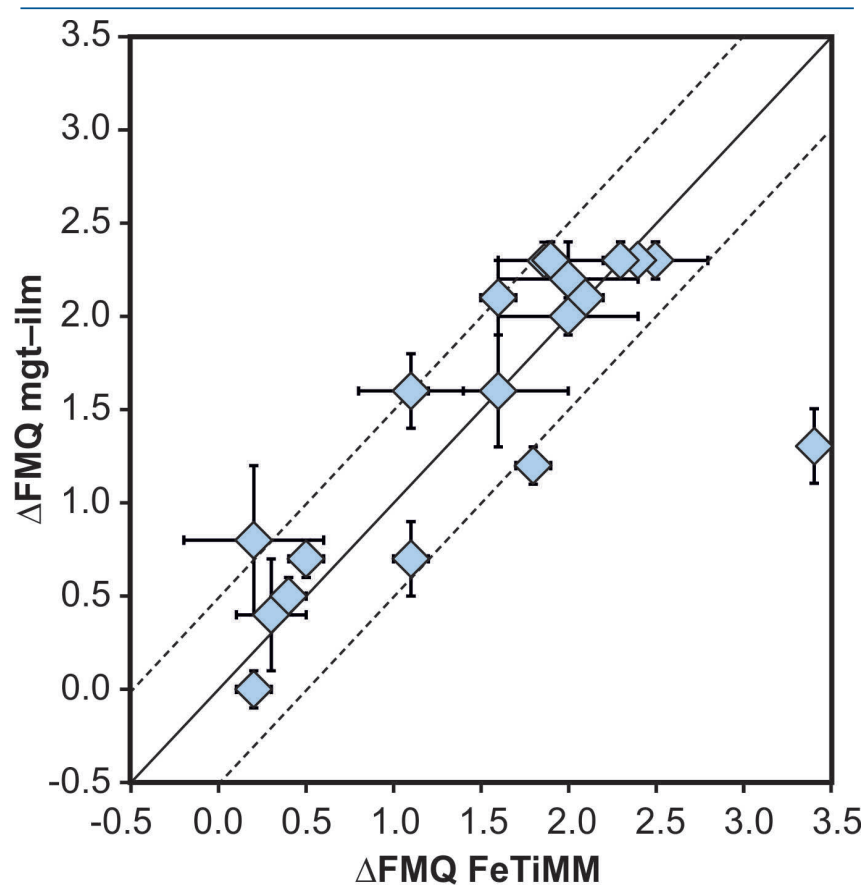

Figure 4 Application of FeTiMM to a set of 19 natural, ilmenite-saturated samples of rhyolitic to dacitic composition (Arató and Audétat, 2017a). Oxygen fugacities (reported in log units relative to the fayalite-magnetite-quartz buffer) obtained via FeTiMM agree within $0.5 \mathrm{log}$ units with those obtained via magnetite-ilmenite oxybarometry (Ghiorso and Evans, 2008) in all but one case. Error bars denote $1 \sigma$ standard deviation of the $\mathrm{fO}_{2}$ values obtained from several magnetite-melt pairs.

\section{Acknowledgements}

This study was financed by German Science Foundation project AU 314/5-1 to A.A.

Editor: Helen Williams

\section{Additional Information}

Supplementary Information accompanies this letter at www. geochemicalperspectivesletters.org/article1740

Reprints and permission information are available online at http://www.geochemicalperspectivesletters.org/ copyright-and-permissions

Cite this letter as: Arató, R., Audétat, A. (2017) FeTiMM - A new oxybarometer for mafic to felsic magmas. Geochem. Persp. Let. 5, 19-23.

\section{References}

Andersen, D.J., Lindsley, D.H. (1988) Internally consistent solution models for Fe-Mg-Mn-Ti oxides: Fe-Ti oxides. American Mineralogist 73, 714-726.

ANDERSEN, D.J., LindsLeY, D.H., DAVIDSON, P.M. (1993) QUILF: A pascal program to assess equilibria among $\mathrm{Fe}-\mathrm{Mg}-\mathrm{Mn}$-Ti oxides, pyroxenes, olivine, and quartz. Computers \& Geosciences 19, 1333-1350.

Arató, R., AudÉtAT, A. (2017a) Vanadium magnetite-melt oxybarometry of natural, silicic magmas: a comparison of various oxybarometers and thermometers. Contributions to Mineralogy and Petrology 172, doi: 10.1007/s00410-017-1369-6.

ARATÓ, R., AudÉTAT, A. (2017b) Experimental calibration of a new oxybarometer for silicic magmas based on vanadium partitioning between magnetite and silicate melt. Geochimica et Cosmochimica Acta 209, $284-295$.

AudétAT, A., Lowenstern, J.B. (2014) Melt inclusions. In: Scott, S.D. (Ed.) Geochemistry of Mineral Deposits. Treatise on Geochemistry, 2nd Edition, Volume 13. Elsevier, Amsterdam, Oxford, Waltham, 143-173.

BACON, C.R., HirschmanN, M.M. (1988) Mg/Mn partitioning as a test for equilibrium between coexisting Fe-Ti oxides. American Mineralogist $73,57-61$.

Ballard, J.R., Palin, M.J., CAmpbell, I.H. (2002) Relative oxidation states of magmas inferred from Ce(IV)/Ce(III) in zircon: application to porphyry copper deposits of northern Chile. Contributions to Mineralogy and Petrology 144, 347-364

BudDington, A., LindsLey, D. (1964) Iron-titanium oxide minerals and synthetic equivalents. Journal of Petrology 5, 310-357.

CARMICHAEL, I.S.E. (1967) The iron-titanium oxides of salic volcanic rocks and their associated ferromagnesian silicates. Contributions to Mineralogy and Petrology 14, 36-64.

Frost, B., LindSLEY, D.H. (1991) Occurrence of iron-titanium oxides in igneous rocks. Reviews in Mineralogy and Geochemistry 25, 433-468.

Frost, B.R., LindSLEY, D. (1992) Equilibria among Fe-Ti oxides, pyroxenes, olivine, and quartz: Part II. Application. American Mineralogist 77, 1004-1004.

Gaillard, F., Scaillet, B., Pichavant, M., BÉnY, J.-M. (2001) The effect of water and $\mathrm{fO}_{2}$ on the ferric-ferrous ratio of silicic melts. Chemical Geology 174, 255-273.

GHIORSO, M.S, EvANS, B.W. (2008) Thermodynamics of rhombohedral oxide solid solutions and a revision of the Fe-Ti two-oxide geothermometer and oxygen-barometer. American Journal of Science 308, 957-1039.

GHIORSO, M.S., SACK, O. (1991) Fe-Ti oxide geothermometry: thermodynamic formulation and the estimation of intensive variables in silicic magmas. Contributions to Mineralogy and Petrology 108, 485-510.

KRESS, V.C., CARMICHAEL, I.S. (1989) The lime-iron-silicate melt system: Redox and volume systematics. Geochimica et Cosmochimica Acta 53, 2883-2892.

Kularatne, K., Audétat, A. (2014) Rutile solubility in hydrous rhyolite melts at $750-900^{\circ} \mathrm{C}$ and $2 \mathrm{kbar}$, with application to titanium-in-quartz (TitaniQ) thermobarometry. Geochimica et Cosmochimica Acta 125, 196-209.

LATTARD, D., SAUerZAPF, U., KÄSEMANN, M. (2005) New calibration data for the Fe-Ti oxide thermo-oxybarometers from experiments in the Fe-Ti-O system at 1 bar, $1,000-1,300^{\circ} \mathrm{C}$ and a large range of oxygen fugacities. Contributions to Mineralogy and Petrology 149, 735-754.

Le Maitre, R.W.B., Dudek, P., Keller, A., Lameyre, J., Le Bas, J., Sabine, M., Schmid, P., Sorensen, R., Streckeisen, H., Woolley, A. (1989) A classification of igneous rocks and glossary of terms: Recommendations of the International Union of Geological Sciences, Subcommission on the Systematics of Igneous Rocks. Blackwell Scientific Publications, Oxford.

LiNDSLEY, D.H., Frost, B.R. (1992) Equilibria among Fe-Ti oxides, pyroxenes, olivine, and quartz; Part I, Theory. American Mineralogist 77, 987-1003.

MacDonald, G.A., Katsura, T. (1964) Chemical composition of Hawaiian lavas. Journal of Petrology 5, 82-133.

Matjuschkin, V., Brooker, R.A., TATtitch, B., Blundy, J.D., StAmper, C.C. (2015) Control and monitoring of oxygen fugacity in piston cylinder experiments. Contributions to Mineralogy and Petrology 169, 9.

PutiRKA, K. (2016) Rates and styles of planetary cooling on Earth, Moon, Mars, and Vesta, using new models for oxygen fugacity, ferric-ferrous ratios, olivine-liquid Fe-Mg exchange, and mantle potential temperature. American Mineralogist 101, 819-840.

Ridolfi, F., Renzulli, A., Puerini, M. (2010) Stability and chemical equilibrium of amphibole in calc-alkaline magmas: an overview, new thermobarometric formulations and application to subduction-related volcanoes. Contributions to Mineralogy and Petrology 160, 45-66. 
SMYTHE, D.J., BREnAN, J.M. (2016) Magmatic oxygen fugacity estimated using zircon-melt partitioning of cerium. Earth and Planetary Science Letters 453, 260-266.

STORMER, J.C. (1983) The effects of recalculation on estimates of temperature and oxygen fugacity from analyses of multicomponent iron-titanium oxides. American Mineralogist 68, 586-594.

Trail, D., Watson, E.B., TAILBy, N.D. (2012) Ce and Eu anomalies in zircon as proxies for the oxidation state of magmas. Geochimica et Cosmochimica Acta 97, 70-87.

WONES, D. (1981) Mafic silicates as indicators of intensive variables in granitic magmas. Mining Geology 31, 191-212.

Wones, D., Eugster, H. (1965) Stability of biotite-experiment theory and application. American Mineralogist 50, 1228-1272.

Xirouchakis, D., Lindsley, D.H., Frost, B.R. (2001) Assemblages with titanite $\left(\mathrm{CaTiOSiO}_{4}\right), \mathrm{Ca}-\mathrm{Mg}-\mathrm{Fe}$ olivine and pyroxenes, Fe-Mg-Ti oxides, and quartz: Part II. Application. American Mineralogist 86, $254-264$. 